\title{
Non-melanoma skin cancer
}

\section{Distribution and natural course are still open questions}

Non-melanoma cancer of the skin and its precursor states are among the most common forms of cancer in Britain with an incidence second only to lung cancer in men and breast cancer in women. Yet despite their high incidence these cancers are among the least adequately studied from a population perspective. This paper examines what is known about their distribution and natural course to identify clinical lessons and some priorities for further research.

We may start by asking why there should be such a contrast between the frequent occurrence of cancers of this type and the relatively low level of interest they arouse. ${ }^{1}$ Firstly, these cancers are seen correctly as less serious than many other forms. The aggressiveness of malignant melanoma has tended to divert attention from the other forms of skin cancer. Yet though malignant melanoma may be twice as important in terms of mortality ( 993 deaths in England and Wales in 1984 compared with 439 deaths from other forms of skin cancer), the registered cases of non-melanoma skin cancer exceed registered cases of malignant melanoma by a factor of 10 (22 254 cases registered in 1984 in England and Wales compared with 2231 cases of malignant melanoma). ${ }^{23}$ Moreover, the numbers quoted for non-melanoma skin cancer are likely to be underestimates: one study found that registrations underestimated its incidence by between $14 \%$ and $28 \%$ even in an area with a highly efficient cancer registry. ${ }^{+}$

A second possible reason for the relative lack of interest in these lesions in Britain compared with countries such as Australia and the United States ${ }^{5-7}$ is that the British climate includes fewer hours of sunshine than many other countries. But this generally negative view of the British climate may distract from the exposure to the sun of certain sections of the population through their occupation, choice of leisure activity, or travel. Furthermore, people of Celtic origin may be at considerably greater risk than other fair skinned people - a finding with obvious implications for the incidence of non-melanoma skin cancer on the western side of the British Isles. ${ }^{8-11}$

Finally, this relative neglect may stem from these lesions being seen as an inevitable concomitant of aging. In fact, the view that the skin changes seen in the elderly are a necessary result of aging is largely mistaken. Comparison of the exposed skin of the face with the unexposed skin of the buttock suggests that environmental factors are more important than the passage of time in producing many of the changes generally associated with aging. ${ }^{12}$

Perhaps the key question is the extent to which the prevalence of non-melanoma skin cancer in the British Isles differs from that in countries where its public health importance is acknowledged. Our examination of published reports suggests that in reality non-melanoma skin cancer may be just as large a public health problem in Britain as it is recognised to be in Australia and the United States.

\section{Descriptive epidemiology}

The epidemiological objective of describing the extent of a disease in a particular locality may be approached in various ways. Some impression can be gained by counting the number of patients who have been treated by the health facilities over time. But in the case of a chronic non-fatal disease, rates derived in this way are likely to reflect the extent to which people seek medical advice and not the true population distribution of the condition. For this reason a community based (as opposed to a health facility based) study on a properly drawn sample is the only reliable means of establishing incidence and prevalence. More formal diagnostic criteria are required for such studies than are conventional in clinical practice. ${ }^{13}$ Several investigators have examined the accuracy of clinical diagnosis in this condition when compared with that of histological diagnosis and have found substantial disparities. ${ }^{1+17}$

The most extensive attempts to examine the distribution of non-melanoma skin cancer have been undertaken in Australia. Some have been based on hospital populations (table) and therefore have an uncertain relation to the prevalence in the population, ${ }^{1821}$ but four studies have been reported in non-hospital populations. Two of these are of limited value either because an atypical population was used ${ }^{19}$ or because the method of case ascertainment was of doubtful validity. ${ }^{20}$ The larger of the two remaining ${ }^{22}{ }^{28}$ sought to examine all those over 40 years living in the town of Maryborough $^{22} ; 2113$ volunteers were examined and suspicious lesions were biopsied. A high prevalence of solar keratoses $(56.9 \%)$ and of non-melanoma skin cancer $(2.32 \%)$ was found. Some $65 \%$ of the eligible population attended, but these were volunteers and the direction and size of any resulting bias is unknown.

Similar problems arise from a study in which 30976 people were asked during a large commercial market research survey whether they had been treated for skin cancer during the previous year. ${ }^{5}$ These diagnoses were validated by contacting the clinicians concerned. The incidence of non-melanoma skin cancer of $823 / 100000$ a year would make this by far the most common cancer in Australia. Not only did the study ultimately rely on medical recognition of cases but also there are problems with the validity of such self reported diagnoses. In this study only $31 \%$ of self reported skin cancers were validated, and the extent to which people who actually had non-melanoma skin cancer but answered the question negatively is unknown.

A number of descriptive studies have also been undertaken in the United States, mostly based on medically recognised cases. ${ }^{29-37}$ Two of these, which were organised by the National Cancer Institute, ${ }^{3132}$ showed that the incidence of nonmelanoma skin cancer in the Minneapolis and San Francisco areas had increased by $3 \%$ a year between 1971 and $1977 .{ }^{37}$

Truly community based studies are as uncommon in the United States as in Australia. In one such study of 978 people the prevalence of non-melanoma skin cancer at all ages was found to be $4.4 \%$; all age prevalence of solar keratoses was $16 \cdot 3 \% .{ }^{23}$ As part of the first national health and nutrition examination survey, which was undertaken between 1971 and 1974, 20749 randomly selected subjects were examined by dermatologists. ${ }^{24}$ The results showed the expected rising 


\begin{tabular}{|c|c|c|c|c|c|c|c|}
\hline Reference & Country & $\begin{array}{l}\text { No of subjects } \\
\text { or cases }\end{array}$ & Nature & $\begin{array}{l}\text { Age of } \\
\text { study group } \\
\text { (years) }\end{array}$ & Incidence ${ }^{\star}$ & Prevalence & Methodological issues \\
\hline $\begin{array}{l}\text { Carmichael and } \\
\text { Silverstone }{ }^{1 \times}\end{array}$ & $\begin{array}{l}\text { Australia } \\
\text { (Queensland) }\end{array}$ & $\begin{array}{l}1000 \text { in each of four } \\
\text { towns }\end{array}$ & $\begin{array}{l}\text { Random sample of } \\
\text { hospital case records }\end{array}$ & All ages & $\begin{array}{l}50 / 10 \% \text { year }(\text { age } 25) \\
1500-4000 / 10 \% \text { year } \\
\quad \text { age } 75)\end{array}$ & & $\begin{array}{l}\text { No definition of tumours studied } \\
\text { Based on hospital cases alone }\end{array}$ \\
\hline Carmichael $^{14}$ & $\begin{array}{l}\text { Australia } \\
\text { (Queensland) }\end{array}$ & $2024(82 \%$ response $)$ & $\begin{array}{l}\text { All members of Farmers } \\
\text { Association }\end{array}$ & $30-50$ & & $\begin{array}{r}\text { Overall } 14 \cdot 4 \text { (includes all skin } \\
\text { cancers and solar keratoses) }\end{array}$ & $\begin{array}{l}\text { Postal questionnaire method with } \\
\text { self diagnosis. Atypical study } \\
\text { population }\end{array}$ \\
\hline $\begin{array}{l}\text { Silverstone } e t \\
a l^{2 *}\end{array}$ & $\begin{array}{l}\text { Australia } \\
\text { (Queensland) }\end{array}$ & $494(82 \%$ response $)$ & $\begin{array}{l}\text { Longstanding residents } \\
(>20 \text { years) in two } \\
\text { locations }\end{array}$ & $>20$ & & $\begin{array}{l}\text { Solar keratoses ( } 53.9 \text { men, } 39.0 \\
\text { women), non-melanoma skin } \\
\text { cancer }(11.3 \text { men, } 9.5 \text { women })\end{array}$ & $\begin{array}{l}\text { Examination by medical students. } \\
\text { No verification by biopsy }\end{array}$ \\
\hline Goodman et al ${ }^{21}$ & Australia (Victoria) & 2000 & Hospital inpatients & $>40$ & & $\begin{array}{l}\text { Skin cancer } 37 \cdot 7, \text { non- } \\
\text { melanoma skin cancer } 3\end{array}$ & $\begin{array}{l}\text { Atypical study population. } \\
\text { Verification by biopsy in } \\
\text { suspected non-melanoma skin } \\
\text { cancer }\end{array}$ \\
\hline Marks et al:2 & Australia (Victoria) & $2113(65 \%$ response $)$ & Population of one town & $>40$ & & $\begin{array}{l}\text { Skin cancer } 56 \cdot 9, \text { non- } \\
\text { melanoma skin cancer } 2 \cdot 3\end{array}$ & $\begin{array}{l}\text { Clinical diagnosis with biopsy of } \\
\text { suspected non-melanoma skin } \\
\text { cancer. Patients attended } \\
\text { screening centre }\end{array}$ \\
\hline Giles et al & Australia & 30976 & Quota sample & $>14$ & $823 / 10 \%$ year & & $\begin{array}{l}\text { Quota sample. Poor validity of self } \\
\text { reporting of treatment for skin } \\
\text { cancer }\end{array}$ \\
\hline $\begin{array}{l}\text { Zagula-Mally et } \\
\text { al }^{33}\end{array}$ & $\begin{array}{l}\text { United States } \\
\text { (Tennessee) }\end{array}$ & 978 Caucasians & $\begin{array}{l}\text { Cluster sampling of } \\
\text { households }\end{array}$ & $>21$ & & $\begin{array}{l}\text { Skin cancer } 16 \cdot 3 \text {, non- } \\
\text { melanoma skin cancer } 4 \cdot 4\end{array}$ & $\begin{array}{l}\text { Examination by trained nurses. No } \\
\text { biopsies }\end{array}$ \\
\hline Johnson et $_{\text {al }} l^{+}$ & United States & $\begin{array}{l}20749(74 \% \\
\text { reponse) }\end{array}$ & $\begin{array}{l}\text { Probability sample of } \\
\text { United States } \\
\text { population }\end{array}$ & $1-74$ & & $\begin{array}{l}\text { All skin cancer } 3 \cdot 6 \text { (age groups } \\
65-74 \text { ) }\end{array}$ & $\begin{array}{l}\text { Clinical examinations by } \\
\text { dermatologists. Survey of all skin } \\
\text { pathology }\end{array}$ \\
\hline Whitaker et al $l^{\text {s }}$ & $\begin{array}{l}\text { United Kingdom } \\
\text { (North West } \\
\text { region) }\end{array}$ & $\begin{array}{l}781 \text { Cases of } \\
\text { squamous cell } \\
\text { carcinoma }\end{array}$ & $\begin{array}{l}\text { All cases reported to } \\
\text { cancer registry } 1967-9\end{array}$ & All ages & $\begin{array}{l}\text { Men } 9 \cdot 5 / 10 / \text { year, } \\
\text { women } 5 \cdot 6 / 10^{\circ} / \text { year }\end{array}$ & & $\begin{array}{l}\text { Confined to squamous cell } \\
\text { carcinoma. Cancer registry cases } \\
\text { alone }\end{array}$ \\
\hline Rea $e t a l^{2 \mathrm{~h}}$ & $\begin{array}{l}\text { United Kingdom } \\
\text { (London) }\end{array}$ & $2180(90 \%$ response $)$ & $\begin{array}{l}\text { Stratified random sample } \\
\text { with private census }\end{array}$ & $15-74$ & & $\begin{array}{l}1 \text { case of non-melanoma skin } \\
\text { cancer. No cases of solar } \\
\text { keratoses }\end{array}$ & $\begin{array}{l}\text { Questionnaire involving self } \\
\text { reporting of skin problems. } \\
\text { Subsample visited by team of } \\
\text { doctors }\end{array}$ \\
\hline O'Beirn et $a l^{4}$ & Ireland & $1338(81 \%$ response $)$ & $\begin{array}{l}\text { Systematic sample of } \\
\text { voters }\end{array}$ & $>21$ & & $\begin{array}{l}\text { All ages. Skin cancer } 10 \cdot 6, \text { non- } \\
\text { melanoma skin cancer } 1 \cdot 9\end{array}$ & $\begin{array}{l}\text { Not specified who undertook } \\
\text { examinations }\end{array}$ \\
\hline
\end{tabular}

${ }^{\star}$ Unless otherwise stated values are percentages.

prevalence of non-melanoma skin cancer with age, with a prevalence of 44/1000 in the age group 65-74 years (number examined $=3466$ ). The rate of solar keratoses in the same age group was surprisingly low at $96 \cdot 3 / 1000$. The possibility arises that the examination, which required information on a wide range of conditions, was perhaps biased towards the more serious diseases under study.

In Britain even less epidemiological information is available. Whitaker et al used three years' data from the North West Cancer Registry and found a crude incidence among men of $9 \cdot 5 / 100000$ a year, ${ }^{25}$ a similar figure to that obtained in Sweden. ${ }^{38}$ Only one community based prevalence study has been undertaken. This examined a wide range of skin conditions in a random population sample in London. ${ }^{2639} \mathrm{~A}$ postal questionnaire was used as a screening device, and a subsample of both positive and negative respondents were visited. Only one case of non-melanoma skin cancer was identified among the original sample of 2180 adults between 15 and 74 years old. No solar keratoses were identified.

A study from Ireland by O'Beirn et al is the only community based prevalence study concerned exclusively with skin cancer that has been performed in north west Europe. ${ }^{9} \mathrm{~A}$ $1 \cdot 5 \%$ systematic sample of the electoral register for Galway was taken; 1338 interviews were conducted $(81 \%$ response rate). The all age prevalence of solar keratoses was $10 \cdot 6 \%$. In men over 70 the prevalence of non-melanoma skin cancer was $14 \%, 12 / 85)$.

These studies are summarised in the table, which shows the inadequacies of the existing epidemiological evidence in terms of the selection of people for study and in terms of adequate validation of findings. The only population of the British Isles to have been examined adequately showed a prevalence of the same order as that suggested by Australian and American studies. ${ }^{9}$ The key implication of the studies reviewed is that the epidemiological pattern of non-melanoma skin cancer in Britain is an open question.

\section{Natural course}

Two questions concern the relation between nonmelanoma skin cancers and previous solar keratoses and the probability of metastasis.

Treatment is often recommended for solar keratoses, though their natural history is poorly documented. During the Maryborough study, however, a longitudinal element was added to the cross sectional investigation. ${ }^{+1}$ People were invited to attend for screening again one year after the initial screen, and half (1040/2113) did so. Solar keratoses were marked on the same chart and any remissions or new keratoses were noted. One quarter $(485 / 1873)$ of the solar keratoses had remitted, and $44 \%$ (458/1040) of subjects had developed at least one new lesion - though identifying these lesions accurately from such charts may have been difficult. A five year follow up of this study has reported that the risk of any one solar keratosis undergoing malignant transformation is less than $0 \cdot 1 \%$ a year. ${ }^{+1}$ The authors suggest that treatment of solar keratoses may be useless in view of their tendency to remit spontaneously and their low potential for malignant change. Indeed solar keratoses may not be premalignant at all. ${ }^{42}$

Many dermatologists might believe, however, that the accurate mapping of lesions as small as solar keratoses is fraught with such difficulties as to call into question the accuracy of these estimates of rate of remission and malignant transformation. Just because, for example, a squamous cell carcinoma develops in the vicinity of a pre-existing solar keratosis it does not necessarily follow that it developed from that lesion or that the prophylactic removal of the keratosis would have prevented the development of the tumour. Dysplastic changes are known to be present in the apparently normal but chronically sun damaged skin around solar keratoses. $^{+3}$

The management of squamous cell cancers of the skin has been strongly influenced by the work of Lund. ${ }^{+}$He reported 
that metastasis occurred in only $0 \cdot 1 \%(4 / 3700)$ of a series of squamous cell cancers of the skin, though the follow up period was not clear in the report. This work has led to a widespread belief that a squamous cell carcinoma developing in a site exposed to sun is very unlikely to metastasise. ${ }^{16}$ Several other studies, however, have suggested higher rates of metastasis. ${ }^{16}{ }^{45-48}$ The two most recent have reported proportions of $2 \cdot 6 \%(6 / 228)^{16}$ and $3 \cdot 3 \%(5 / 153)^{48}$ - though again the length of follow up was unclear.

The probability of metastasis from basal cell carcinoma is also contentious. ${ }^{49}$ Beerman suggested a figure of between $0 \cdot 1 \%$ and $0.54 \%{ }^{50}$ whereas an Australian survey reported the much lower proportion of $0.0028 \%$ (14/estimated 500000 ), ${ }^{51}$ though neither study specified the duration and success of follow up. In short, the question of the natural course of solar keratoses and non-melanoma cancer of the skin is in important respects still an open one.

\section{Conclusions}

Most non-melanoma skin cancers in white populations are due to ultraviolet radiation, and a change in habits with regard to exposure to sun could greatly reduce their incidence..$^{52-54}$ Public awareness campaigns have been launched in Australia, South Africa, the United States, and Britain. ${ }^{556}$ The emphasis of much of the publicity has been on the relation between exposure to sun and malignant melanoma - for the understandable reasons that melanoma is the most aggressive form of skin cancer, that it tends to affect a younger age group, and because its incidence has shown a steady increase. ${ }^{12}$ It is important to note, however, that the exact nature of the relation between malignant melanoma and

1 Urbach F. Cancer of the skin. In: Bourke GJ, ed. The epidemiology of cancer. London: Croom Helm, 1983:102-15.

2 Office of Population Censuses and Surveys. 1984 Mortality statistics: cause. London: HMSO, 1985 (Series DH2 No 11.)

3 Office of Population Censuses and Surveys. 1984 Cancer statistics: registrations. London: HMSO 1988. (Series MB1 No 16 .)

4 Beadle PC, Bullock D, Bedford G, et al. Accuracy of skin cancer incidence data in the United Kingdom. Clin Exp Dermatol 1983;7:255-60.

5 Giles GG, Marks R, Foley P. Incidence of non-melanocytic skin cancer treated in Australia. Br Med f 1988;296:13-7.

6 Marks R. Skin cancer-Australia's bicentennial celebration. Med f Aust 1985;143:433-4.

7 Marks R. Non-melanoma skin cancer and solar keratoses in Australia - a review. Eur $\mathcal{F}$ Epidemiol $1985 ; 1: 319-22$.

8 Lane Brown MM, Sharpe CAB, Macmillan DS, McGovern VJ. Genetic predisposition to melanoma and other skin cancers in Australians. Med $\mathcal{F}$ A ust 1971; ; :852-3.

9 O'Beirn SF, Judge P, Urbach F, MacCon CF, Martin F. Skin cancer in County Galway, Ireland. Proceedings of the National Cancer Conference, Philadelphia 1970;6:489-500.

10 Urbach F. Geographic distribution of skin cancer. F Surg Oncol 1971;3:219-34.

11 Marks R. Premalignant disease of the epidermis. F R Coll Physicians Lond 1986;20:116-21.

12 Mackie RM, Elwood JM, Hawk JLM. Links between exposure to ultraviolet radiation and skin cancer. I R Coll Physicians Lond 1987;21:91-6.

13 Jones DL, Jones HS. Conditions that mimic skin cancer. Fournal of Dermatologic Surgery 1976;2:209-14.

14 Lightstone AC, Kopf AW, Garfinkel L. Diagnostic accuracy - a new approach to its evaluation. Arch Dermatol 1965;91:497-502.

15 Presser SE, Taylor JR. Clinical diagnostic accuracy of basal cell carcinoma. 7 Am Acad Dermatol 1987;16:988-90.

16 Nixon RL, Dorevitch AP, Marks R. Squamous cell carcinoma of the skin: accuracy of clinical diagnosis and outcome of follow-up in Australia. Med f Aust 1986;144:235-9.

17 Ponsford MW, Goodman G, Marks R. The prevalence and accuracy of diagnosis of non-melanotic skin cancer in Victoria. Australasian fournal of Dermatology 1983;24:79-82.

skin cancer in Victoria. Australasian fournal of Dermatology 1983;24:79-82.
18 Carmichael GG, Silverstone H. The epidemiology of skin cancer in Queensland: the incidence. Brf Cancer 1961;15:409-24.

19 Carmichael GG. A survey of skin cancers and solar keratoses in country areas in Queensland. Med F Aust 1962;i:395-400

20 Silverstone H, Campbell CB, Hosking CS, Lang LP, Richardson RG. Regional studies in skin cancer. First report: north western Queensland. Med f Aust 1963;i:312-5.

21 Goodman GJ, Marks R, Selwood TS, Ponsford MW, Pakes W. Non-melanotic skin cancer and solar keratoses in Victoria-clinical studies II. Australasian fournal of Dermatology 1984;25 103-6.

22 Marks R, Ponsford MW, Selwood TS, Goodman G, Mason G. Non-melanotic skin cancer and solar keratoses in Victoria. Med f Aust 1983;ii:619-22.

23 Zagula-Mally ZW, Rosenberg EW, Kashgarian M. Frequency of skin cancer and solar keratoses in a rural southern county as determined by population sampling. Cancer 1974;34:345-9.

24 Johnson M-LT, Roberts J. Skin conditions and related need for medical care among persons $1-74$ years, United States 1971-74. Washington: United States Government Printing Office, 1978. (Vital and health statistics series 11 No 212 .)

25 Whitaker CJ, Lee WR, Downes JE. Squamous cell skin cancer in the North-West of England, 1967-69, and its relation to occupation. Br f Ind Med 1979;36:43-51.

26 Rea JN, Newhouse ML, Halil T. Skin disease in Lambeth. British fournal of Preventive and Social Medicine 1976;30:107-14.

27 Silverstone H, Gordon D. Regional studies in skin cancer. Second report: wet tropical and subtropical coasts of Queensland. Med F Aust 1966;ii:733-40.

28 Quirk CJ. Skin disease in the Busselton Population survey. Med F Aust 1979;i:569-70. exposure to sun is still a matter of some debate ${ }^{1}$ and that the probability of developing malignant melanoma is small when compared with the probability of developing non-melanoma skin cancer. The release of chlorofluorocarbons and nitrogen oxides into the upper atmosphere may be severely depleting the ozone layer, which protects us from most of the ultraviolet B component in solar radiation. ${ }^{57}$ It has been estimated that for every $1 \%$ decline in the ozone layer there will be a $2-3 \%$ increase in the incidence of non-melanoma skin cancer. ${ }^{58}$ Adequate baseline measures of the distribution of these lesions are essential if we are to be able to measure any such changes in incidence.

Studies of the natural course of non-melanoma skin cancer show the largest uncertainty to be with solar keratosesthat is, their potential for malignant transformation and their tendency to remit spontaneously. Reliable data are of substantial clinical importance as the time and effort devoted to treating solar keratoses may well be unnecessary.

I HARVEY

Wellcome Lecturer in Clinical Epidemiology D SHALOM

Research Registrar in Medicine

R M MARKS

Professor of Dermatology

University of Wales College of Medicine, Cardiff CF 4 XN

S J FRANKEL Senior Lecturer in Community Medicine

Health Care Evaluation Unit,

Department of Epidemiology and Community Medicine, Bristol BS8 2PR

29 Lynch FW, Seidman H, Hammond EC. Incidence of cutaneous cancer in Minnesota. Cancer 1970;25:83-91

30 Schreiber MM, Shapiro SI, Berry CZ, Dahlen RF, Friedman RP. The incidence of skin cancer in Southern Arizona (Tucson). Arch Dermatol 1971;104:124-7.

31 Scotto J, Kopf AW, Urbach F. Non-melanoma skin cancer among caucasians in four areas of the United States. Cancer 1974;34:1333-8.

32 Scotto J, Fears TR, Fraumeni JF Jr. Incidence of non-melanoma skin cancer in the United States. Bethesda, Maryland: United States Department of Health and Human Services, 1983. (Nationa Institutes of Health publication No 83-2433.)

33 Mason EE, Nance M, Radcliffe CE, Scotto J, Berg JW. Skin cancer in Iowa. Journal of Iowa Medical Society 1974;64:469-72.

34 Allison SD, Wong KL. Skin cancer: some ethnic differences. Arch Dermatol 1957;76:737-9.

35 Macdonald EJ. The epidemiology of skin cancer. $\mathcal{F}$ Invest Dermatol 1959;32:379-82.

36 Haenszel W. Variations in skin cancer incidence within the United States. In: Urbach F, ed. The biology of cutaneous cancer. Washington, DC: United States Gorvernment Printing Office, biology of cutaneous cancer. Washington, DC: United States
1963:225-43. (National Cancer Institute Monograph No 10.)

37 Fears TR, Scotto J. Changes in skin cancer morbidity between 1971-72 and 1977-78. fNCI 982;69:365-70

38 Swanbeck G, Hillstrom L. Analysis of etiological factors of squamous cell skin cancer of different locations. 4. Concluding remarks. Acta Derm Venereol (Stockh) 1971;51:151-6.

39 Holland WW, Waller J. Population studies in the London borough of Lambeth. Community Med 1971;126:153-6.

40 Marks R, Foley P, Goodman G, Hage BH, Selwood TS. Spontaneous remission of solar keratoses: the case for conservative management. Br f Dermatol 1986;115:649-55.

41 Marks R, Rennie G, Selwood TS. Malignant transformation of solar keratoses to squamous cell carcinoma. Lancet 1988;i:795-7.

42 Carmichael GG. The epidemiology of skin cancer in Queensland: the significance of pre-malignant conditions. Br f Cancer 1961;15:425-8.

43 Pearse AD, Marks R. Actinic keratoses and the epidermis on which they arise. Br $\mathcal{F}$ Dermatol 1977;96:45-50.

44 Lund HZ. How often does squamous cell carcinoma of the skin metastasise? Arch Dermatol 1965;92:635-7.

45 Epstein E, Epstein NN, Bragg K, Linden G. Metastases from squamous cell carcinomas of the kin. Arch Dermatol 1968;97:245-9.

46 Immerman SC, Scanlon EF, Christ M, Knox KL. Recurrent squamous cell carcinoma of the skin Cancer 1983;51:1537-40

47 Katz AD, Urbach F, Lilienfeld AM. The frequency and risk of metastases in squamous-cell carcinoma of the skin. Cancer 1957;10:1162-6.

48 Moller R, Reymann F, Hou-Jensen K. Metastases in dermatological patients with squamous cell carcinoma. Arch Dermatol 1979;115:703-5.

49 Domarus HV, Stevens PJ. Metastatic basal cell carcinoma. I Am Acad Dermatol 1984;10:1043-60.

50 Beerman H. Some aspects of cutaneous malignancy. Arch Dermatol 1969;99:617-26.

51 Paver K, Poyzer K, Burry N, Deakin M. The incidence of basal carcinoma and their metastases in Australia and New Zealand. Australasian fournal of Dermatology 1973;14:53.

52 Fitzpatrick TB, Sober AJ. Sunlight and skin cancer. N Engl F Med 1985;313:818-9.

53 Urbach F. Ultraviolet radiation and skin cancer in man. Prev Med 1980;9:227-30.

54 Fears TR, Scotto J, Schneiderman MA. Mathematical models of age and ultraviolet effects on the incidence of skin cancer among whites in the United States. Am f E pidemiol 1977;105:420-7.

55 Doherty VR, Mackie RM. Reasons for poor prognosis in British patients with cutaneous malignant melanoma. Br Med f 1986;292:987-9.
mela

56 Rigel DS, Friedman RJ, Kopf AW, et al. Importance of complete cutaneous examination for the detection of malignant melanoma. $\mathcal{F}$ Am Acad Dermatol 1986;14:857-60.

57 Jones RR. Ozone depletion and cancer risk. Lancet 1987;ii:443-6.

58 Beadle PC, Leach JF. Holidays, ozone and skin cancer. Arch Dermatol Res 1982;274:47-56. 